\title{
Assessment of an extraction protocol to detect the major mastitis-causing pathogens in bovine milk
}

\author{
B. Cressier* and N. Bissonnette ${ }^{*} t^{1}$ \\ *Département de Biochimie, Faculté de Médecine et des Sciences de la Santé, Université de Sherbrooke, QC, Canada J1H 5N4 \\ †Dairy and Swine Research and Development Centre, Agriculture and Agri-Food Canada, Sherbrooke, QC, Canada J1M 1Z3
}

\begin{abstract}
Despite all efforts to control its spread, mastitis remains the most costly disease for dairy farmers worldwide. One key component of better control of this disease is identification of the causative bacterial agent during udder infections in cows. Mastitis is complex, however, given the diversity of pathogens that must be identified. Development of a rapid and efficient bacterial species identification tool is thus necessary. This study was conducted to demonstrate the feasibility of bacterial DNA extraction for the automated molecular detection of major mastitis-causing pathogens directly in milk samples to complement traditional microbiological identification. Extraction and detection procedures were designed and optimized to achieve detection in a respectable time frame, at a reasonable cost, and with a high throughput capacity. The following species were identified: Staphylococcus aureus, Escherichia coli, Streptococcus uberis, Streptococcus agalactiae, Streptococcus dysgalactiae, and Klebsiella spp. (including Klebsiellaoxytoca and Klebsiellapneumoniae). The detection procedure includes specific genomic DNA amplification by multiplex PCR for each species, separation by capillary electrophoresis, and laser-assisted automated detection. The specificity of the primers was assessed with a panel of bacteria representing mastitis-negative control species. The extraction protocol comprised multiple steps, starting with centrifugation for fat removal, followed by heating in the presence of a cation exchange resin to trap divalent ions. The analytical sensitivity was $100 \mathrm{cfu} / \mathrm{mL}$ for milk samples spiked with Staph. aureus, Strep. dysgalactiae, and E.coli, with a tendency for K. pneumoniae. The detection limit was $500 \mathrm{cfu/}$ $\mathrm{mL}$ for Strep. uberis and Strep. agalactiae. The overall diagnostic sensitivity (95.4\%) and specificity (97.3\%) were determined in a double-blind randomized assay by processing 172 clinical milk samples with microbiological characterization as the gold standard. When the
\end{abstract}

Received July 30, 2010.

Accepted January 26, 2011.

${ }^{1}$ Corresponding author: nathalie.bissonnette@agr.gc.ca physical nature of the milk samples was too altered, DNA purification with a magnetic bead-based system was used. Of the apparent false-positive samples, 5 were identified by specific microbiological analysis as truepositive Staph. aureus co-infections, with further confirmation by ribosomal $16 \mathrm{~S}$ sequencing. The proposed methodology could, therefore, become an interesting tool for automated PCR detection of major mastitis pathogens in dairy cattle.

Key words: bovine intramammary infection, multiplex polymerase chain reaction (PCR), sensitivity, specificity

\section{INTRODUCTION}

In recent years, dairy farm management and hygiene improvement programs have been established in many countries, decreasing the number of reported cases of mastitis. However, mastitis remains the most important disease for the dairy industry: in the United States, the mean estimated cost per clinical case, taking into account decreased milk yield, premature culling, and veterinary treatments, is US\$179 (Bar et al., 2008). Therefore, more measures still need to be taken to lower the effect of this disease on the income of dairy farmers. One such measure is identification of the causative agent. Once the agent is identified, appropriate measures, whether antibiotics, isolation of the affected cattle to prevent the spread of contagious mastitis, or even culling, can be implemented.

Mastitis-causing pathogens have traditionally been detected and identified with microbiological cultures and biochemical tests. This process is time-consuming and does not allow the analysis of bronopol-preserved composite milk samples, because the identification of nonviable bacteria is impaired. Moreover, an important fraction (20 to $30 \%$ ) of the milk samples taken from udders with clinical mastitis test negative (Taponen et al., 2009, and references within). A large proportion of these no-bacterial-growth results are recognized as false negatives, because the conventional microbiological methods failed to detect most of the bacterial species found in the milk samples, whereas molecular detection confirmed the presence of bacterial genomic DNA. 
These microbiologically negative samples often contain several common mastitis pathogens, some of them even displaying high bacteria counts, as shown by a quantitative PCR detection assay (Taponen et al., 2009).

Molecular detection assays are a promising avenue to resolve those false negative issues, and many assays have already been developed (Santos et al., 2008; Koskinen et al., 2009; Kuang et al., 2009; Supré et al., 2009; Taponen et al., 2009). For several reasons, a multiplex PCR-based assay could be best suited for identifying mastitis-causing pathogens (Gillespie and Oliver, 2005). The main benefit of multiplex PCR over other molecular methods is its cost: it is cheaper because all species can be amplified in a single reaction. With real-time PCR methods, the number of different targets that can be amplified is limited to 4 per reaction because each target carries a different dye whose individual emission spectrum must not overlap the others for specific detection. With capillary electrophoresis systems, multiplex PCR reactions yield fragments that can be identified both by their specific fragment length and by their respective fluorescent emission. Whereas real-time PCR is based on specific fluorescent emission, fragment length analysis by capillary electrophoresis accounts for both.

The main goal of this study was to devise a mastitis pathogen extraction and detection procedure for use on raw milk samples without further enrichment, despite the altered physical complexity of clinical milk. The work was focused on achieving a low-cost, highthroughput capacity, and fast turnaround time. The bacterial species targeted for identification in milk were Staphylococcus aureus, Escherichia coli, Streptococcus uberis, Streptococcus agalactiae, Streptococcus dysgalactiae, and Klebsiella spp. (including Klebsiella oxytoca and Klebsiella pneumoniae). The molecular assay included a positive detection control that was added at the extraction step, namely Lactobacillus rhamnosus, a species that is not found in the lactating mammary gland with or without the occurrence of mastitis. The proposed method includes an extraction procedure suitable for all of the species to be detected. As a result of the use of $5^{\prime}$-marker dyes associated with each forward primer set in the multiplex PCR reaction, discrimination among target species is based on dye signals as well as the capacity of capillary electrophoresis to separate PCR products based on fragment length, as a result of the multiplexed design. Resolution and sensitivity are increased in comparison with agarose gel electrophoresis. Because the capillary electrophoresis apparatus contains genetic analysis software, identification of PCR products is automated. This methodology is a good way to increase high-throughput analysis by keep- ing costs low in the development of a new alternative PCR-based assay.

\section{MATERIALS AND METHODS}

\section{Clinical Milk Samples and Conventional Microbiological Analysis}

Mastitic milk samples were taken from cows showing signs of clinical mastitis in commercial dairy herds. All of the mastitic samples were collected by veterinarians during the daily practice of the ambulatory clinic and sent to the clinical bacteriology laboratory at the Faculté de Médecine Vétérinaire of the Université de Montréal, Montreal, QC. Mastitis milk samples were defined according to criteria of the International Dairy Federation (IDF, 1999). The milk samples were kept on ice during transport and inoculated on reception onto a tryptic soy agar (TSA) plate, enriched with 5\% sheep blood (BBL; Becton Dickinson and Co., Cockeysville, MD). The analyses were performed according to National Mastitis Council (NMC) guidelines (NMC, 2004). Following this first analysis, these mastitic samples were sent to the authors' laboratory, where a second and independent microbiological analysis was carried out. An aliquot of the stock $(0.1 \mathrm{~mL})$ was plated on TSA esculin blood agar plates (5\% defibrinated sheep blood), and the remainder of the sample was aliquoted and kept frozen until molecular analysis. Bacterial growth, colony morphology, and hemolysis patterns were observed after incubation at $37^{\circ} \mathrm{C}$ for $24 \mathrm{~h}$, and a second reading was taken at $48 \mathrm{~h}$. The morphological characteristics (e.g., color, form) following Gram staining were registered. The samples showing a positive reaction to Gram staining were further characterized by catalase and tube coagulase tests (BBL). Catalase- and coagulase-positive isolates were classified as Staph. aureus. Catalase-negative gram-positive cocci were classified as Strep. agalactiae, Strep. dysgalactiae, and Strep. uberis, based on their capacity to hydrolyze hippurate, to perform fermentation of trehalose, mannitol, and sorbitol, to grow on $5 \mathrm{M} \mathrm{NaCl}$, and to express the CAMP factor. Esculin hydrolysis, although found variable for Streptococcus species, was also performed. Gram-negative colonies were streaked on MacConkey agar plates and in Simmons citrate agar tubes. Isolates showing negative reactions were identified as E. coli, and colonies showing positive reactions were further tested with motility indone ornithine (MIO) medium for identification of K. pneumoniae and K. oxytoca. All media and biochemical test reagents were from Quelab Laboratories Inc. (Montreal, QC), unless otherwise indicated. 
The mastitic samples were classified as single-infected when only 1 species was detected by the microbiological analysis and dual-infected when 2 species were detected. Contaminated samples, defined as showing growth of 3 or more pathogens from the same sample, were excluded, as described elsewhere (Dingwell et al., 2003). All samples were processed according to the Chelex (Bio-Rad Laboratories Ltd., Mississauga, ON, Canada) DNA extraction and multiplex PCR detection protocol.

\section{Chelex DNA Extraction}

The DNA extraction protocol is intended to directly process 1-mL samples of crude milk using a 96-well plate-compatible liquid workstation. The milk was first clarified by adding $0.5 \mathrm{~mL}$ of $0.5 \mathrm{M}$ EDTA (MJS BioLynx Inc., Brockville, ON; Grattepanche et al., 2005 ) and $0.1 \%$ Tergitol 15-S-07 (The Dow Chemical Company, Varennes, QC). Following incubation for $10 \mathrm{~min}$ at room temperature, the clarified milk samples were centrifuged at $13,000 \times g$ for $10 \mathrm{~min}$. The supernatant, including the fat fraction, was discarded. The pellet was washed twice with $1 \mathrm{~mL}$ of molecular-grade water, resuspended in $20 \mu \mathrm{L}$, and incubated at $37^{\circ} \mathrm{C}$ for $30 \mathrm{~min}$ with $0.4 \mu \mathrm{g}$ of lysostaphin (Sigma-Aldrich Co., Oakville, ON), unless stated otherwise. The DNA extraction included Chelex (iminodiacetic acid) ionic resin and rapid boil treatments as described elsewhere (Weisburg et al., 1991; Giraffa et al., 2000; Kim et al., 2001) but with minor modifications. In that process, $180 \mu \mathrm{L}$ of a $10 \%$ Chelex-100 slurry (Bio-Rad Laboratories Ltd.) was added. The pellet was boiled at $100^{\circ} \mathrm{C}$ for $10 \mathrm{~min}$ and chilled on ice for $10 \mathrm{~min}$. After centrifugation at $13,000 \times g$ for $5 \mathrm{~min}$, the supernatant was transferred to a clean tube. The aliquots were kept at $-80^{\circ} \mathrm{C}$ until they were used as templates for PCR. An additional purification step was included in the protocol for samples with heavy physical alterations like clots and flakes; that step involved magnetic beads for DNA purification, as described elsewhere (Day et al., 2009). The GenFind V2 DNA purification protocol (Agencourt Bioscience Corp., Beverly, MA), designed for blood or tissue samples, was adapted for milk samples. The supernatants obtained from the Chelex slurry boiling step $(200 \mu \mathrm{L})$ were mixed with $400 \mu \mathrm{L}$ of lysis buffer and $9 \mu \mathrm{L}$ of proteinase $\mathrm{K}$ and incubated at $37^{\circ} \mathrm{C}$ for $10 \mathrm{~min}$. The binding buffer $(300 \mu \mathrm{L})$, containing magnetic beads, was added and mixed by pipetting. After $5 \mathrm{~min}$ at room temperature, DNA was captured by the magnetic beads, and the plate was transferred onto the magnetic plate for $15 \mathrm{~min}$. The supernatant was discarded. The plate was taken off the magnet, and the DNA beads were washed twice with $800 \mu \mathrm{L}$ and
$500 \mu \mathrm{L}$ of wash buffer 1 and wash buffer 2 , respectively. The plate was then put back on the magnet to discard the supernatant. The captured DNA was eluted with $40 \mu \mathrm{L}$ of elution buffer. All of the chemicals used for this step were supplied with the GenFind V2 kit (Agencourt Bioscience Corp.).

\section{Analytical Specificity}

The primers listed in Supplementary Table 1 (available online at http://www.journalofdairyscience.org/) are specific to a genomic region or gene for each species, as reported elsewhere (footnote, Supplementary Table1). The primers were synthesized by Applied Biosystems Inc. (Foster City, CA). The Basic Local Alignment Search Tool (BLAST) of the GenBank nucleotide database (http://www.ncbi.nlm.nih.gov/) was used for in silico validation of perfect similarity with the respective specific regions. Standard PCR-based reactions were used to confirm the unique gene target and species specificity. Polymerase chain reactions were carried out in $25-\mu \mathrm{L}$ volumes containing $2.5 \mu \mathrm{L}$ of $10 \mathrm{X}$ buffer $(200 \mathrm{~m} M$ Tris- $\mathrm{HCl}, \mathrm{pH} 8.4,200 \mathrm{~m} M \mathrm{KCl}$, Tween 20 , and enzyme stabilizers), $1.5 \mathrm{mM} \mathrm{MgCl}, 0.2 \mathrm{~m} M$ of each deoxynucleoside triphosphate (dNTP), $0.2 \mu M$ of each primer, $1 \mathrm{U}$ of Taq polymerase (BioShop Canada Inc., Burlington, ON), $10 \mathrm{ng}$ of purified template DNA, and $18 \mu \mathrm{L}$ of HyClone molecular biology-grade water (Thermo Scientific Inc., Logan, UT). To test the analytical sensitivity of the PCR design, a total of 295 strains isolated from mastitic milk samples and analyzed by conventional microbiological analysis were used: 60 Staph. aureus, 56 Strep. uberis, 46 Strep. dysgalactiae, 40 Strep. agalactiae, $61 \mathrm{E}$. coli, $27 \mathrm{~K}$. pneumoniae, and $4 \mathrm{~K}$. oxytoca strains. The cetyl trimethyl ammonium bromide (CTAB)/ $\mathrm{NaCl}$ DNA extraction method (Wilson, 2001) was used to purify genomic DNA from bacterial culture. A selection of the most pertinent negative control species was also extracted (Supplementary Table 2, available online at http://www.journalofdairyscience. org/). These control species were included on the basis of 2 main criteria: closely related phylogenetic analysis, and the probability of finding them in bovine milk samples. The bacterial genomic DNA was quantified using an ND-1000 spectrophotometer (NanoDrop Technologies Inc., Wilmington, DE). To validate the specificity of the primers, the PCR products were separated by electrophoresis through a 1.5\% (wt/vol) agarose gel in Tris-acetate-EDTA (TAE) buffer $(40 \mathrm{~m} M$ Tris-acetate, $1 \mathrm{~m} M$ EDTA, $\mathrm{pH}$ 8.4) and stained with $0.5-\mu \mathrm{g} / \mathrm{mL}$ ethidium bromide (Sigma-Aldrich Co.), and the results were recorded using the FluorChem SP imaging system (Cell Biosciences Inc., Santa Clara, CA). 


\section{Analytical Sensitivity}

To determine the analytical sensitivity of the molecular detection, milk samples were artificially contaminated with a bacterial load of known cfu, as described elsewhere (Quaglia et al., 2005). For the bacterial spiking assays, milk samples were aseptically collected as described elsewhere (Roy et al., 2007) from healthy dairy cows, defined based on several observations (e.g., normal appetite, locomotion, and behavior) including normal milk appearance (e.g., no bacterial growth) for several consecutive samplings over a 3 -wk period. The absence of pathogens was confirmed by plating several aliquots of $100-\mu \mathrm{L}$ aliquots of milk on TSA plates.

The cfu aliquots used in the spiked-milk assays were prepared from a log culture. An overnight culture was used as a starter to prepare the fresh bacterial culture, which was then grown for 3 to $5 \mathrm{~h}$. Gram-negative bacteria were washed with PBS, whereas $0.05 \%$ Triton X-100 (Sigma-Aldrich Co.) was added to the wash buffer for gram-positive bacteria. The log culture was serially diluted, and aliquots were stored at $-80^{\circ} \mathrm{C}$ in $20 \%$ glycerol. The bacterial dispersion was confirmed by visual examination under a microscope. Several aliquots of each dilution stock were serially diluted, when required, and plated on tryptic soy broth (TSB) plates to evaluate the concentration $(\mathrm{cfu} / \mathrm{mL})$ of the working stock. The concentration of frozen stock was periodically evaluated to confirm bacterial viability. To determine the analytical sensitivity of the extraction procedure, $50 \mu \mathrm{L}$ of the appropriately diluted stock culture was spiked in $950 \mu \mathrm{L}$ of pathogen-free milk. All samples were processed according to the Chelex DNA extraction and multiplex PCR detection protocol.

\section{Multiplex PCR and Fragment Length Analysis}

Multiplex PCR was performed using the panel of primers (at the concentrations indicated in Supplementary Table 1, available online at http://www. journalofdairyscience.org/) and Multiplex PCR Master Mix (Qiagen Inc., Mississauga, ON) according to the manufacturer's instructions with slight modifications. The primer mix included each target set comprising the forward and reverse primers. Reactions were carried out in $25-\mu \mathrm{L}$ volumes, which included $2 \times$ Master PCR Mix volumes (including $\mathrm{MgCl}_{2}$, dNTP, and hotstart DNA polymerase in an optimized buffer), $5 \mu \mathrm{L}$ of primer mix, $0.4 \mathrm{mM}$ deoxyuridine triphosphate (dUTP; Fermentas Canada Inc., Burlington, ON), $0.15 \mathrm{U}$ of uracil-DNA-glycosylase (Invitrogen Canada Inc., Burlington, ON), $2 \mu \mathrm{L}$ of template DNA, and sterile HyClone water (Thermo Scientific) to bring the total volume to $25 \mu \mathrm{L}$. In the presence of dUTP and
uracil-N-glycosylase (UNG; Invitrogen), a pre-PCR incubation step at $37^{\circ} \mathrm{C}$ for $10 \mathrm{~min}$ was performed in a Biometra TGradient thermocycler (Montreal Biotech Inc., Montreal, QC). The PCR conditions consisted of an initial activation (hot-start) step at $95^{\circ} \mathrm{C}$ for $15 \mathrm{~min}$, followed by 35 cycles of amplification $\left(95^{\circ} \mathrm{C}\right.$ for $30 \mathrm{~s}$, $59^{\circ} \mathrm{C}$ for $90 \mathrm{~s}$, and $72^{\circ} \mathrm{C}$ for $30 \mathrm{~s}$ ) and a final extension step at $72^{\circ} \mathrm{C}$ for $10 \mathrm{~min}$. For fragment length analysis by capillary electrophoresis, $1 \mu \mathrm{L}$ of a 1-in-10 dilution of each PCR product was analyzed with a 96 -well plate containing $8.8 \mu \mathrm{L}$ of deionized formamide and $0.2 \mu \mathrm{L}$ of LIZ-500 size standard (Applied Biosystems). The samples were incubated at $95^{\circ} \mathrm{C}$ for $3 \mathrm{~min}$ and chilled on ice for $10 \mathrm{~min}$. Capillary electrophoresis was performed with Performance Optimized Polymer-4 (POP4; Applied Biosystems) on an ABI Prism 3100-Avant Genetic Analyzer (Applied Biosystems). The samples were injected at $1 \mathrm{kV}$ for $20 \mathrm{~s}$ and electrophoresed at a constant voltage of $15 \mathrm{kV}$ for $25 \mathrm{~min}$ at $60^{\circ} \mathrm{C}$. Raw data were treated by GeneMapper software (Applied Biosystems) with the allele recognition feature. This simultaneous detection involved a fragment length analysis further discriminated by the nature of the dye used for the PCR (Supplementary Table 1, available online at http://www.journalofdairyscience.org/). Each electropherogram was visualized to confirm the concurrence of the data regarding the shape of the peaks.

\section{Carry-Over Contamination Control}

The use of UNG into the PCR reactions prevents contamination by previously amplified DNA (carryover) when deoxythymidine triphosphate (dTTP) is substituted for dUTP (Longo et al., 1990), an approach that was introduced for molecular diagnosis by real-time PCR (Pruvost et al., 2005). The dUTP residues were included in the Multiplex PCR Master Mix (Qiagen Inc.), which already contains all 4 dNTP. To evaluate the adequate incorporation of uracil residues, both dUTP incorporation and the UNG treatment were optimized. A first multiplex PCR reaction was performed using $10 \mathrm{ng}$ of purified genomic DNA with increasing amounts of dUTP (0 to $1,000 \mu M$ ). These first PCR products mimicked contaminations that were serially diluted and used as templates in a second multiplex $\mathrm{PCR}$ reaction. Prior to that second reaction, the different amplified PCR products $(0$ to $1,000 \mu M$ ) were treated with UNG. The UNG-treated PCR products were analyzed by fluorescent fragment analysis. This method made it possible to evaluate the minimum concentration of dUTP required to eliminate the simulated carry-over contamination without affecting PCR amplification. The efficient degradation of the uracilcontaining template was confirmed by the absence of 
a PCR product in the second reaction, as detected by capillary electrophoresis.

\section{Sequencing}

Sequencing reactions were processed in 2 instances during this study. First, to confirm the specificity of primers, the PCR products amplified by each primer pair listed in Supplementary Table 1 (available online at http://www.journalofdairyscience.org/) were sequenced. Second, when a false-positive PCR product arose from milk sample analysis, further identification was performed by sequencing the $16 \mathrm{~S}$ rRNA gene. To recover Staph. aureus or E. coli (including Klebsiella spp.) from the false-positive samples, milk was plated on selective media, namely mannitol salt agar for Staph. aureus and MacConkey agar for E. coli. Strains were selected, and standard PCR was performed on bacterial genomic DNA using the universal forward primer 27F (AGAGTTTGATCMTGGCTCAG; Weisburg et al., 1991) and reverse primer 788R (GGACTACCAGGGTATCTAA; Therese et al., 1998) with the following conditions: initial denaturation step of $94^{\circ} \mathrm{C}$ for $3 \mathrm{~min}, 35$ cycles of amplification $\left(94^{\circ} \mathrm{C}\right.$ for $30 \mathrm{~s}, 47^{\circ} \mathrm{C}$ for $90 \mathrm{~s}$, and $72^{\circ} \mathrm{C}$ for $60 \mathrm{~s}$ ), and final amplification at $72^{\circ} \mathrm{C}$ for $10 \mathrm{~min}$. The PCR products were purified on NucleoSpin Extract II purification columns (MJS BioLynx), and DNA was quantified using an ND-1000 spectrophotometer. Sequencing reactions were carried out using BigDye chemistry (Applied Biosystems) as described by the manufacturer. The sequences obtained were compared with the GenBank database (Benson et al., 2010) using the BLAST tool (Altschul et al., 1990). Identified genera of putative isolates grown from false-positive samples were analyzed using the Sequence Match tool from the Ribosomal Database Project (Cole et al., 2009).

\section{Diagnostic Sensitivity and Specificity}

For the molecular investigation, all the mastitic milk samples were assigned a random number and used in a double-blind randomized assay. Analysis was carried out on 172 mastitic milk samples. Molecular diagnostic results for the milk samples were compared with microbiological identification, the gold standard. The diagnostic sensitivity is the ability to detect by molecular assay the pathogen found by conventional microbiological culture. The diagnostic sensitivity was determined as follows: (number of true positives)/(number of true positives + number of false negatives $) \times 100$. The diagnostic specificity is the ability to obtain a negative signal for the pathogen when not detected by culture and was determined as follows: (number of true negatives among the 153 milk samples)/(number of true negatives + number of false positives) $\times 100$ (Martin, 1984). In each dual-infected milk sample, both species had to be identified to mark the sample as a true positive. A threshold of 300 relative fluorescence units (RFU) on the electropherogram was set for identifying a result as positive for a given targeted species in processed milk samples from clinical mastitis cases.

\section{Statistical Analysis}

Basic statistical analyses were performed using Excel, and an ANOVA (assuming unequal variances) was performed using SAS (Statistical Analysis System, Release 9.1, 2002; SAS Institute Inc., Cary, NC) with a Tukey correction for multiple comparisons among concentration levels. A nonparametric analysis (KruskalWallis test; not shown) was used for further confirmation of statistical significance.

\section{RESULTS}

\section{Rapid Boiling and Chelex-100 Treatment}

The protocol is rapid and technically easy, not requiring the use of lysis detergent, corrosive and toxic organic solvents, high-salt precipitation, and columnbased purification system. The method includes a first centrifugation step. The presence of EDTA to clarify milk by disrupting the micelles substantially decreased micelle precipitation and, therefore, the volume of the pellet, leaving a small white trace in most milk samples. In the absence of the detergent, centrifugation of the raw milk produced an upper fat layer that was difficult to discard and left substantial lipid residuals that hindered subsequent PCR assays. The addition of Tergitol partially homogenized the raw milk, leaving a thin and very fluid fat layer that was easily discarded by decantation. Concentrations of Tergitol detergent ranging from 0.01 to $1 \%$ were tested. No significant improvement in the physical appearance of the milk centrifuged in the presence of $0.01 \%$ Tergitol was observed. Both 0.1 and $1 \%$ Tergitol improved the fluidity of the fat layer. The use of $1 \%$ detergent significantly decreased the recovery and viability of L.rhamnosus (in both the pellet and the fat layer) but did not affect the recovery of Staph. aureus in the pellet. The effect of Tergitol on the viability of L.rhamnosus was much milder at $0.1 \%$ than at $1 \%$, whereas no effect on viability was observed for the other species using $0.1 \%$ Tergitol. As a result, the following experiments were performed with $0.1 \%$ Tergitol. The molecular detection was tested using raw milk artificially contaminated with known amounts of cfu prepared from bacterial culture. The analytical 
sensitivity of the method was determined using bacterial genomic DNA extracted using the rapid boiling method either alone or with Chelex-100. The rapid boiling treatment allowed the PCR-based detection of all of the pathogens tested, including L. rhamnosus, used as an external spiking control for the extraction method. The addition of Chelex-100 improved pathogen detection over a broad range of cfu concentrations. The resin is known to be a strong chelator of divalent ions and could also protect genomic DNA from damage by these ions at high temperatures. The resin might trap calcium ions from milk or other PCR inhibitors, because an increased amount of resin improved detection. The presence of inhibitors was confirmed when it was observed that boiling the sample in larger volumes resulted in better detection for mastitic milk samples. The detection limits of the Chelex-based milk-derived DNA purification protocol observed by agarose gel electrophoresis analysis were generally established at $10^{3}$ bacteria/mL milk (data not shown).

The addition of lysostaphin at the cell-wall lysis step improved the detection of Staph. aureus. Whereas $40 \mu \mathrm{g}$ of lysostaphin in a $20-\mu \mathrm{L}$ volume inhibited the downstream PCR amplification (Figure 1, lanes 1 to 2), 0.4 $\mu \mathrm{g}$ was sufficient to recover DNA from milk samples contaminated with $10^{3}$ or $10^{4} \mathrm{cfu}$ (Figure 1, lanes 5 and 6 , respectively).

\section{Optimization of UNG-dUTP}

Carry-over contamination is an important topic for diagnostic laboratory applications. To avoid the carry-over PCR amplification of former amplicons in

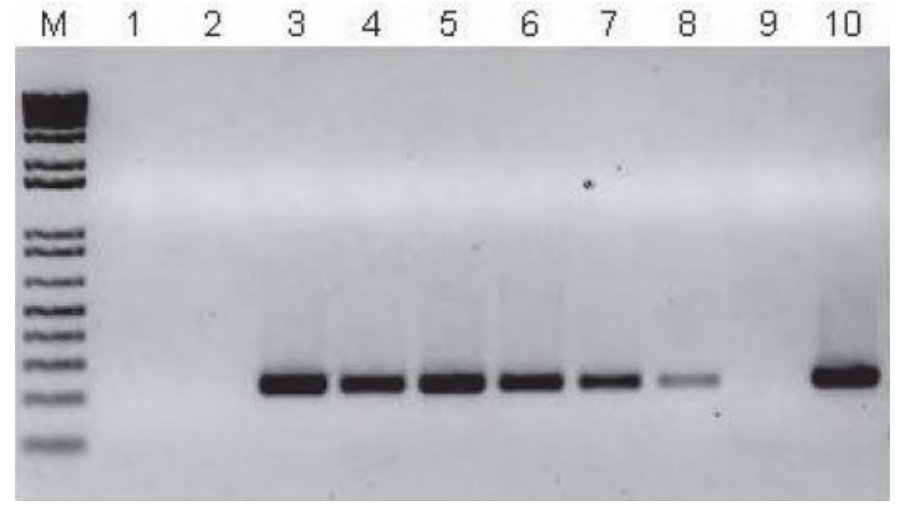

Figure 1. Effect of lysostaphin treatment on detection of Staphylococcus aureus. Milk samples were treated with $40 \mu \mathrm{g}$ (lanes 1 and 2), $4 \mu \mathrm{g}$ (lanes 3 and 4), or $0.4 \mu \mathrm{g}$ (lanes 5 and 6) of lysostaphin, or without lysostaphin (lanes 7 and 8). Milk samples were spiked with $10^{4}$ (lanes 1, 3, 5, and 7) or $10^{3}$ (lanes 2, 4, 6, and 8) cfu Staph. aureus/ $\mathrm{mL}$. Lane 9, no-template control; lane 10, PCR control (10 ng genomic DNA); lane M, 100-bp DNA ladder. a subsequent reaction, dUTP residues were added to the Multiplex PCR Master Mix. The incorporation of dUTP was optimized because this ready-mix PCR buffer already contains dNTP, which includes dTTP, the dUTP nucleotide competitor. For all of the tested gene targets, a concentration above 600 to $800 \mu M$ dUTP inhibited the PCR reaction. With an artificial carry-over contamination approach, the appropriate concentration of dUTP and UNG to inhibit subsequent amplification was evaluated using fluorescent fragment analysis by capillary electrophoresis, as described in the Materials and Methods section. The conditions that prevented PCR inhibition and enabled the complete degradation of the PCR contamination were found to be $400 \mu M$ dUTP and $0.15 \mathrm{U}$ of UNG (data not shown).

\section{Standard and Multiplex PCR}

The analytical specificity of the primer pairs designed to target genes specific to each pathogen was tested by standard PCR and analyzed by agarose gel electrophoresis. The analytical specificity of the PCR assay was confirmed using bacterial DNA isolated from a culture prepared with a strain isolated from the mastitic milk samples. The specificity of the primer design was confirmed on the following strains: 60 Staph. aureus, 56 Strep. uberis, 46 Strep. dysgalactiae, 40 Strep. agalactiae, 61 E. coli, 27 K. pneumoniae, and 4 K. oxytoca strains. A representative result for the analysis of E. coli and K. pneumoniae is shown in Figure 2. The molecular analytical specificity of the PCR was $100 \%$ for all targets tested both in standard and multiplex PCR using purified bacterial genomic DNA (data not shown), with the exception of 1 case. Whereas this clinical case was qualified as E. coli by both laboratories, it was molecularly positive for both wecA and khe. Further analysis revealed an additional gram-negative strain present in the milk sample that was confirmed to be Raoultella planticola by rpoB sequencing in 2006 and further confirmed by multilocus sequence typing (MLST) by Ruth Zadoks, Cornell University, Ithaca, New York (data not shown). The molecular test cannot distinguish Klebsiella spp. from R. planticola, whereas the microbiological assay cannot distinguish E.coli from $R$.planticola. This gram-negative mastitis case was analyzed as false positive for Klebsiella spp. Supplementary Table 2 (available online at http://www.journalofdairy science.org/) summarizes the species used as negative controls. The PCR-based design generated amplicons ranging from 109 to $281 \mathrm{bp}$ (Supplementary Table 1, available online at http://www.journalofdairyscience. org/) that produced the same fragment length profiles, as detected by both agarose gel (Figure 3a) and capillary (Figure 3b) electrophoresis. 


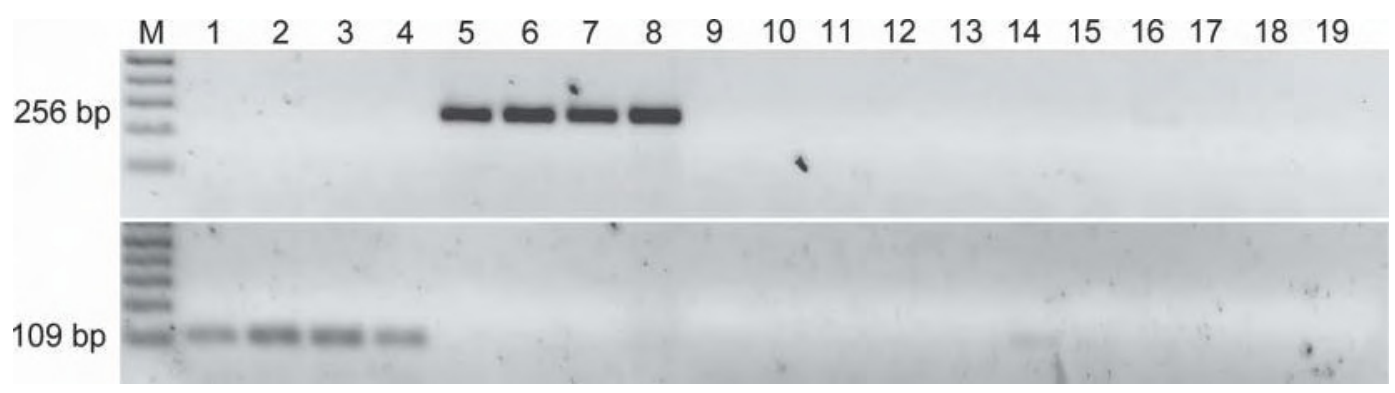

Figure 2. Primer specificity assessment with positive and negative control species. The PCR reactions were performed with Escherichia coli primers (upper panel) and Klebsiella spp. (lower panel) using $10 \mathrm{ng}$ of bacterial genomic DNA purified from the following: lanes 1 and 2 , Klebsiellapneumoniae; lanes3 and 4, Klebsiellaoxytoca; lanes5, 6, 7, and 8, E.coli; lane9, Pasteurella multocida; lane10, Proteus mirabilis; lane11, Proteus vulgaris; lane 12, Pseudomonas aeruginosa; lane 13, Pseudomonas putida; lane 14, Raoultella planticola; lane 15, Salmonella enteritidis; lane 16, Salmonella typhimurium; lane 17, Serratia marcescens; lane 18, Yersinia enterolitica; lane 19, no-template control; lane M, 100-bp DNA ladder.

\section{Recovery and Analytical Sensitivity from Milk Samples}

To assess the analytical sensitivity of the PCR-based system, the Chelex-100 boiling extraction procedure was tested with the 6 most prevalent mastitis pathogens at concentrations of $100,500,1,000$, and $5,000 \mathrm{cfu} / \mathrm{mL}$ of raw milk. The mean RFU values measured in 3 independent experiments using fragment length analysis by capillary electrophoresis are shown in Figure 4 . The fluorescent PCR-based system increased the sensitivity compared with the agarose gel electrophoresis analysis, with a detection limit of $100 \mathrm{cfu} / \mathrm{mL}$ for Staph. aureus $(P=0.001)$, Strep. dysgalactiae $(P=0.037)$, L. rhamnosus $(P=0.007)$, and $E$. coli $(P=0.005)$, and a tendency for K.pneumoniae $(P=0.079)$. The detection limit was $500 \mathrm{cfu} / \mathrm{mL}$ for Strep. uberis $(P=0.022)$ and Strep. agalactiae $(P=0.014)$. Detection was quantitative for spiked milk at concentrations ranging from 100 to $5,000 \mathrm{cfu} / \mathrm{mL}$ for most pathogens, including E. coli (tendency; $P=0.063$ ), which was found to be significant, using nonparametric Kruskal-Wallis analysis $(P=$ $0.023)$. The exception was Strep. agalactiae $(P=0.086)$, which presented important detection variability among replicates. For the milk samples spiked with more than $5,000 \mathrm{cfu} / \mathrm{mL}$, saturation of the signal from the Genetic Analyzer detector was reached $(\sim 8,000 \mathrm{RFU})$, and detection was no longer quantitative but did remain qualitative. For the clinical milk sample analysis, setting the detection threshold at 300RFU resulted in the limit of the fluorescent capillary electrophoresis system using the Chelex PCR-based DNA extraction procedure being defined as quantitative within the $1-\log 10$ range of 500 to $5,000 \mathrm{cfu} / \mathrm{mL}$ of milk and as qualitative for a broad range above the pathogen respective detection limits $(100-500 \mathrm{cfu} / \mathrm{mL})$. The method allows detection of subclinical forms of intramammary infections, which were selected based on elevated SCC $(>250,000$ cells/ $\mathrm{mL}$ ), but not detected by the herdsman because of the absence of apparent clinical signs (local herd, data not shown).

\section{Clinical Milk Sample Analysis}

A total of 172 milk samples from cows with clinical mastitis were characterized by 2 independent laboratories using standard microbiological methods. Of these samples, 153 contained 1 of the bacterial species targeted in this study, and 19 contained 2species (Tables 1 and 2 , respectively). The results are classified according to this microbiological identification, on which both laboratories agreed. To challenge the extraction protocol and the PCR-based detection assay, these samples were processed accordingly (Chelex DNA Extraction section, Materials and Methods), and the results are summarized in Tables 1 and 2. Of the 153 samples infected by a single pathogenic species, 7 were not detected by the molecular analysis (false negatives), and 24 false-positive targets were identified (Table 1). The most frequently encountered false-positive result was for E. coli ( 7 cases), followed by Staph. aureus (6 cases, not 10). Of the 19 samples from which 2 bacterial species were identified (dual infection), the combination of Staph. aureus and Strep. dysgalactiae was the most frequent, being found 13 times. The clinical milk samples identified as containing 2 species displayed a higher rate of false results, with 4 false-positive and 5 false-negative results obtained among 19samples (Table2).

\section{Adaptation of the GenFind V2 DNA Purification Protocol}

For some of the mastitic samples, the physical appearance of the milk was altered by the presence of clots and flakes. These alterations hindered the extraction procedure and impaired the PCR-based molecular detection. The GenFind V2 magnetic-bead system was introduced to further purify DNA from these Chelex- 
a)

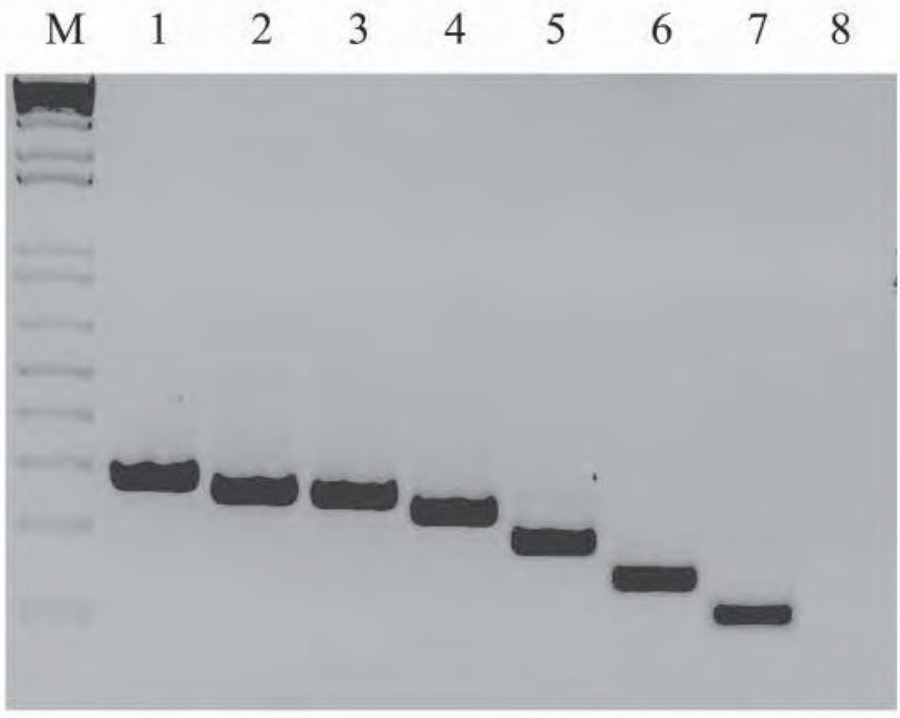

b)

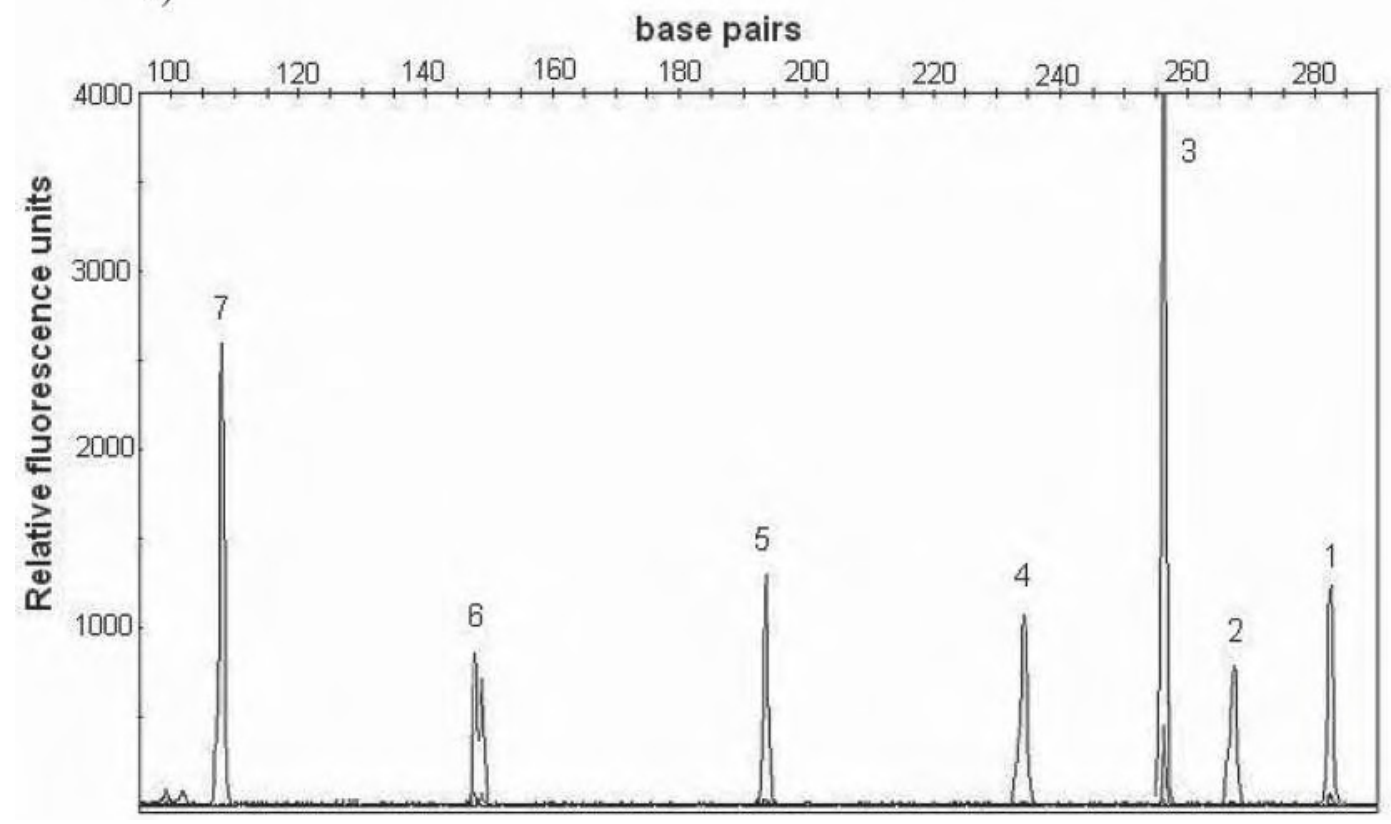

Figure 3. Electrophoresis of multiplex PCR. The PCR reactions were performed on individual species (a) and with a pool of purified genomic DNA (b). The equivalent of 10 and $0.1 \mu \mathrm{L}$ of the PCR reactions were analyzed by agarose gel electrophoresis (a) and capillary electrophoresis (b), respectively. Lane/peak1, Lactobacillus rhamnosus; lane/peak2, Escherichia coli; lane/peak 3, Streptococcus dysgalactiae; lane/ peak4, Staphylococcus aureus; lane/peak5, Streptococcus agalactiae; lane/peak6, Streptococcus uberis; lane/peak 7, Klebsiella pneumoniae; lane8, no-template control; lane M, 100-bp DNA ladder.

treated DNA samples. That system allowed the specific identification of 17 pathogens in milk samples that were considered to be false negatives among the 172 clinical milk samples analyzed with the Chelex-based DNA protocol. These 17 results were obtained mainly from mastitic milk samples containing clots and flakes. The
GenFind V2 magnetic-bead system increased the diagnostic sensitivity by almost $10 \%$.

\section{Diagnostic Sensitivity and Specificity}

The overall diagnostic sensitivity of the assay was $95.4 \%$, and the overall diagnostic specificity was $96.9 \%$. 
Table 1. Cross-classification of the Chelex ${ }^{1}$ PCR-based results obtained from the analysis of 153 single-infected milk samples ${ }^{2}$

\begin{tabular}{|c|c|c|c|c|c|c|c|}
\hline \multirow[b]{2}{*}{$\begin{array}{l}\text { Microbiological } \\
\text { identification }^{3}\end{array}$} & \multicolumn{7}{|c|}{ Molecular identification } \\
\hline & $\begin{array}{c}\text { Staphylococcus } \\
\text { aureus }\end{array}$ & $\begin{array}{c}\text { Streptococcus } \\
\text { uberis }\end{array}$ & $\begin{array}{l}\text { Streptococcus } \\
\text { dysgalactiae }\end{array}$ & $\begin{array}{l}\text { Streptococcus } \\
\text { agalactiae }\end{array}$ & $\begin{array}{l}\text { Escherichia } \\
\text { coli }\end{array}$ & $\begin{array}{c}\text { Klebsiella } \\
\text { pneumoniae } \\
\text { and Klebsiella oxytoca }\end{array}$ & $\begin{array}{c}\text { False } \\
\text { negative }\end{array}$ \\
\hline Staphylococcus aureus $(\mathrm{n}=52)$ & 50 & 2 & & & 3 & & 2 \\
\hline Streptococcus uberis $(\mathrm{n}=27)$ & $2^{4}$ & 25 & 2 & & 2 & & 2 \\
\hline Streptococcus dysgalactiae $(\mathrm{n}=29)$ & $7^{4}$ & & 28 & & 2 & 1 & 1 \\
\hline Streptococcus agalactiae $(\mathrm{n}=9)$ & & & & 9 & & & 0 \\
\hline Escherichia coli $(\mathrm{n}=25)$ & 1 & & 1 & 1 & 25 & $1^{5}$ & 0 \\
\hline Klebsiella pneumoniae and Klebsiella oxytoca $(\mathrm{n}=11)$ & & & & & & 9 & 2 \\
\hline Total $(\mathrm{n}=153)$ & 60 & 27 & 31 & 10 & 32 & 10 & \\
\hline False positive & 4 & 2 & 3 & 1 & 7 & 2 & \\
\hline
\end{tabular}

${ }^{1}$ Bio-Rad Laboratories Ltd. (Mississauga, ON, Canada).

${ }^{2}$ Values in bold correspond to bacterial species for which the molecular diagnosis was concordant with the microbiological diagnosis.

${ }^{3}$ Samples were processed according to National Mastitis Council standards by 2 independent laboratories.

${ }^{4}$ Further microbiological analysis on selective media confirmed the presence of the pathogens in some of these samples despite the absence of detection during the initial microbiological identification.

${ }^{5}$ Further molecular analysis confirmed the identity of Raoultella planticola by rpoB sequencing and further multilocus sequence typing (MLST) analysis (laboratory of R. Zadoks, Cornell University, Ithaca, NY).

Table 2. Cross-classification of the Chelex ${ }^{1}$ PCR-based results for 19 dual-infected milk samples

\begin{tabular}{|c|c|c|c|c|c|c|c|}
\hline \multirow[b]{2}{*}{$\begin{array}{l}\text { Microbiological } \\
\text { identification }\end{array}$} & \multicolumn{7}{|c|}{ Molecular identification } \\
\hline & $\begin{array}{c}\text { Staphylococcus } \\
\text { aureus }\end{array}$ & $\begin{array}{c}\text { Streptococcus } \\
\text { uberis }\end{array}$ & $\begin{array}{l}\text { Streptococcus } \\
\text { dysgalactiae }\end{array}$ & $\begin{array}{l}\text { Streptococcus } \\
\text { agalactiae }\end{array}$ & $\begin{array}{c}\text { Escherichia } \\
\text { coli }\end{array}$ & $\begin{array}{c}\text { Klebsiella } \\
\text { pneumoniae } \\
\text { and Klebsiella oxytoca }\end{array}$ & $\begin{array}{c}\text { False } \\
\text { negative }\end{array}$ \\
\hline Staphylococcus aureus and Streptococcus dysgalactiae $(\mathrm{n}=13)$ & 9 & 1 & 13 & & $2^{2}$ & & 4 \\
\hline Staph. aureus and Streptococcus uberis $(\mathrm{n}=2)$ & 2 & 2 & 1 & & & & 0 \\
\hline Klebsiella pneumoniae and oxytoca and Streptococcus uberis $(\mathrm{n}=1)$ & & & & & & 1 & 1 \\
\hline Escherichia coli and Strep. uberis $(\mathrm{n}=1)$ & & 1 & & & 1 & & 0 \\
\hline Staph. aureus and Strep. agalactiae $(\mathrm{n}=1)$ & 1 & & 1 & 1 & & & 0 \\
\hline E. coli and Strep. dysgalactiae $(\mathrm{n}=1)$ & & & 1 & & 1 & & 0 \\
\hline Total $(\mathrm{n}=19)$ & 12 & 4 & 16 & 1 & 4 & 1 & 5 \\
\hline False positive & 0 & 1 & 2 & 0 & 1 & 0 & 4 \\
\hline
\end{tabular}

$\lesssim \quad{ }^{1}$ Bio-Rad Laboratories Ltd. (Mississauga, ON, Canada).

$\stackrel{\bullet}{\triangleright} \quad{ }^{2}$ Further microbiological analyses revealed the presence of E.coli in one of these samples. 
One clinical sample that was initially identified as a single infection of $E$. coli was found to be positive for both wecA (E. coli) and khe (Klebsiella spp.). However, further characterization revealed the presence of E. coli (wecA) and R.planticola (khe), both gram-negative species (data not shown). Table 3 summarizes the PCRbased diagnostic sensitivity and specificity values for the clinical samples identified as containing only 1 bacterial species by means of the gold standard detection method (microbiological analysis). In a previous study, it was determined that adding Lactobacillus spp. to milk samples could dislodge Staph. aureus from the cream fraction of milk and generate more productive data (Graber et al., 2007). In the present study, different concentrations of L.rhamnosus were spiked in mastitic milk samples. Although the presence of L.rhamnosus did not improve Staph. aureus detection or bacterial displacement from the fat layer (data not shown), the addition of this species to milk samples before extraction was useful for optimization and the detection of false-negative results, interpreted as PCR inhibition or pellet loss.

\section{Microbiological False-Negative Results Highlighted by Molecular Detection}

Whenever a false-positive result was obtained by molecular detection, the corresponding milk samples were further analyzed on selective media to isolate the species that could explain the molecular result. For 6 false-positive results associated with Staph. aureus, this methodology led to isolation of the putative Staph. aureus pathogen in milk; the identity of that pathogen was then confirmed by sequencing, morphology, and biochemical characteristics (catalase- and coagulasepositive test results). Six of the samples initially identified as single-infected, 4 as positive for Strep.dysgalactiae and 2 as positive for Strep. uberis, were effectively identified as dual-infected. This highlights the fact that microbiological identification generated 6 false-negative Staph. aureus results. Considering these 6 results, the PCR-based diagnostic specificity for Staph. aureus detection was revised from 90.1 to $96.0 \%$. One similar case with an apparent false-positive E. coli result for a clinical dual-infected sample was reported, having been bacteriologically diagnosed as Strep. dysgalactiae and Staph. aureus. This milk sample was streaked on MacConkey agar, and the presence of lactose-positive colonies combined with $16 \mathrm{~S}$ rRNA sequencing confirmed the presence of E. coli in this sample.

\section{Multiplex PCR Detection of Mycobacterium avium ssp. paratuberculosis}

Primers amplifying the IS900 gene used for the detection of Mycobacterium avium ssp. paratuberculosis
(MAP) were tested on milk samples collected from 29 clinically infected cows whose infection status was confirmed by ELISA, culturing, and PCR-based analysis of the feces. Chelex PCR-based analysis of milk samples from the $29 \mathrm{MAP}$-positive cows did not generate PCR amplicons, whereas a positive signal was detected by standard PCR using bacterial lysates purified from the respective bacterial culture (data not shown).

\section{DISCUSSION}

This study is the first to report a high-throughput multiplex PCR analysis of raw milk without any bacterial enrichment. The results showed a high diagnostic sensitivity of $95.4 \%$ and an overall diagnostic specificity of $97.3 \%$. Bacterial species were selected on the basis of their prevalence in Canadian dairy herds (Olde Riekerink et al., 2008) and the severity of the symptoms that they cause. Even though more recent literature suggests that CNS can also be the causative agent of mastitis cases, CNS was only found in 6 among the 172 cases selected based on mastitis clinical signs, which might explain the low prevalence of CNS in the present study. The uncertainty of this question (detection in milk with and without mastitis) and the difference in the analytical approach (intergenic fragment fingerprint; Supré et al., 2009) limited the molecular design to the prevalent and well-defined pathogens found in clinical milk.

The main goal of the assay was to detect the most prevalent mastitis-causing species found in raw milk without the time-consuming and biased enrichment step. The enrichment step may, however, be required for pathogens present in low abundance, as in the case of mycoplasma mastitis (Biddle et al., 2003) or bovine paratuberculosis infections (Giese and Ahrens, 2000), mainly because those pathogens are found in milk in very low amounts $(<100 \mathrm{cfu} / \mathrm{mL})$. Because the multiplex PCR assay is based on the identification of bacterial DNA, it is neither based on biological functionality nor dependent on bacterial viability. The analysis could be integrated into milk monitoring schemes using bronopol-preserved milk. Using the proposed protocol, the results were reported within the same working day: genomic DNA was extracted from raw milk within $2 \mathrm{~h}$, followed by the multiplex PCR assay $(3 \mathrm{~h})$ and the fragment length analysis by capillary electrophoresis (30 min/sample, 32 samples/h for the 16-capillary detection system). The common methods used for DNA purification involve a corrosive and toxic organic solvent, such as phenol (Tan and Yiap, 2009). Thus, organic liquid-liquid phase handling, high-salt precipitation, and alcohol precipitation are to be avoided because of poor feasibility, given that the high-throughput analysis is 


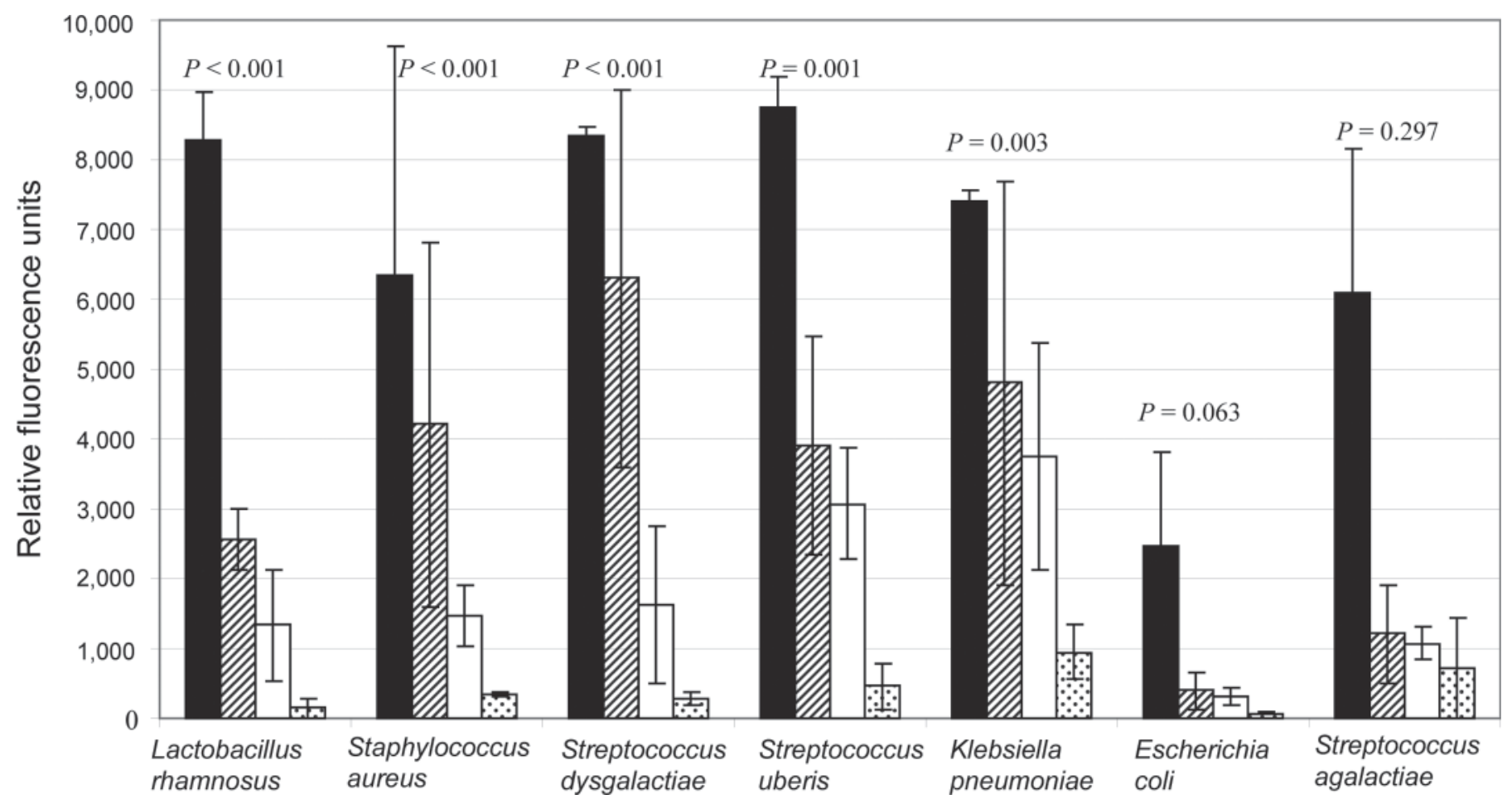

Figure 4. Analytical sensitivity assessment for milk samples artificially contaminated with the major mastitis-causing pathogens. The relative fluorescence units obtained following capillary electrophoresis are the results of 3independent experiments, reported as means and standard error of the means for each pathogen spiked at the following concentrations: 5,000 (solid bar), 1,000 (dashed bar), 500 (open bar), and 100 (spotted bar) cfu/mL.

inappropriate when working with 96- or 384-well plates. Other methods involve column-based purification systems, which are less suitable for high-throughput analysis than magnetic bead-based methods (Siddiqui et al., 2009; Tan and Yiap, 2009). Spin column-based purification is also incompatible with some mastitic milk. Huge variance exists in the physical appearance of mastitic milk samples, and the formation of clogs hinders the use of columns (data not shown). Focusing on simple milk separation processes makes it possible to work safely and properly in multi-well plates without significantly affecting the amplifiable DNA yield. An additional advantage concerns the economical aspect of the method. The overall reagent cost per 7-species analysis is less than US $\$ 5$ per milk sample.

Moreover, the multiplex PCR assay is flexible. For example, the gene sua (Luther et al., 2008) was also validated for all Strep. uberis isolates (data not shown) and could, therefore, have replaced pauA in the multiplex PCR assay (data not shown). Primer sets specific to virulence factors of interest (e.g., $\beta$-lactam) could also be considered in the detection assay. In addition, another detection scheme could be combined within the multiplex PCR assay, such the fingerprinting of the RNA-intergenic spacer sequence (i.e., tDNA-PCR) for the detection of CNS because both are based on the capillary electropherogram profile (Supré et al., 2009). This DNA sequence-based species identification method using capillary electrophoresis is currently the most accurate species identification method available (Zadoks and Watts, 2009). In contrast to the real-time PCR assay, the different fragment length analyses combined with the numerous fluorescent dyes in multiplex PCR amplify the detection capacity of the assay. The introduction of additional pathogens or virulence factors into the detection system is, thus, a matter of design, namely discrimination based on both amplicon length and the 4 fluorescent dyes. The PCR-based scheme presented here is the basis for a field performance trial that is economically viable because it also presents the advantage of automatic extraction and detection procedures. Assuming that proper equipment is in place, this approach could be used in any routine bacteriological laboratory, regardless of the operator experience.

The robustness of the Chelex boiling extraction and PCR-based detection procedure was shown by the microbiological false-negative results revealed by molecular detection of 6 cases associated with Staph. aureus. The overgrowth of some pathogens can mask the detection of others and, thus, bias the microbiological analysis. This fact has been highlighted by the molecular detection of Staph. aureus, which had not 
Table 3. Diagnostic sensitivity and specificity of the PCR-based analysis of clinical mastitis samples

\begin{tabular}{|c|c|c|c|c|c|c|}
\hline Targeted species (gene) & $\begin{array}{l}\text { True } \\
\text { positive }\end{array}$ & $\begin{array}{c}\text { False } \\
\text { negative }\end{array}$ & $\begin{array}{c}\text { Diagnostic } \\
\text { sensitivity }(\%)\end{array}$ & $\begin{array}{c}\text { True } \\
\text { negative }^{1}\end{array}$ & $\begin{array}{l}\text { False } \\
\text { positive }\end{array}$ & $\begin{array}{c}\text { Diagnostic } \\
\text { specificity }(\%)\end{array}$ \\
\hline Staphylococcus aureus (nuc) & 50 & 2 & 96.2 & 95 & 6 & 94.1 \\
\hline $\begin{array}{l}\text { Streptococcus dysgalactiae } \\
\text { (16S-23S intergenic region) }\end{array}$ & 28 & 1 & 96.6 & 121 & 3 & 97.6 \\
\hline Streptococcus uberis (pauA) & 25 & 2 & 92.6 & 124 & 2 & 98.4 \\
\hline Escherichia coli $($ wecA) & 25 & 0 & 100 & 121 & 7 & 94.5 \\
\hline Klebsiella pneumoniae (khe) & 9 & 2 & 81.8 & 140 & 2 & 98.6 \\
\hline
\end{tabular}

${ }^{1}$ True negative results were calculated for each species based on the 153 single-infected samples tested in the double-blind randomized molecular assay.

been found during the first microbiological analysis but was later detected by specific culture and confirmed by sequencing the intergenic ribosomal gene. Although an inherent proportion of false-positive results is obtained when clinical samples are analyzed, the occurrence of false positives for the major mastitis pathogens was relatively low with the proposed approach compared with other methods. For instance, microarray analysis using $16 \mathrm{~S}$ ribosomal hybridization probes generated a higher proportion of false-positive results $(10$ per 50 clinical milk samples; Cremonesi et al., 2009).

The extraction and detection method devised in the present study is reproducible and has been successfully challenged with raw milk samples spiked with different pathogens. The sensitivity was as low as 100 to $500 \mathrm{cfu} / \mathrm{mL}$ for the 6 most prevalent mastitis pathogens tested using the spiked-milk method. The sensitivity is similar to that reported in other research. For example, EDTA/SDS-based extraction methods performed following pronase enzymatic digestion with an overnight TSB enrichment step showed sensitivity of 100 to $1,000 \mathrm{cfu} / \mathrm{mL}$ for Staph. aureus, Strep. uberis, and Strep. agalactiae (Gillespie and Oliver, 2005); the sensitivity for Lactococcus lactis ssp. cremoris without preculture was $200 \mathrm{cfu} / \mathrm{mL}$ (Grattepanche et al., 2005). However, extraction protocols using organic solvent and Triton X-100 achieved greater sensitivity, with detection of $10 \mathrm{cfu} / \mathrm{mL}$ for Staph. aureus, Strep. agalactiae, Strep. dysgalactiae, and Strep. uberis (Cremonesi et al., 2006) and for Shigella and E. coli (Riyaz-Ul-Hassan et al., 2009). Commercial PCR-based milk analyses are available, but their sensitivity is limited. For example, the PathoProof Mastitis PCR Assay (Finnzymes Oy, Espoo, Finland) achieved a much lower sensitivity, from 2,230 to more than $10^{7}$ bacterial genome copies per $1 \mathrm{~mL}$ of milk (Taponen et al., 2009). Furthermore, the PathoProof assay involves a real-time PCR approach for which the number of detected bacterial species is limited to 4 targets per PCR assay because of the respective spectra of the combined fluorescent dyes, which cannot overlap for specific detection. This commercial detection assay is performed using spin columns, which the authors of the present study found to be incompatible with physically altered mastitic samples (data not shown). The sensitivity is, thus, much less than the conventional microbiological analysis, for which the detection limit on Petri dishes is $10 \mathrm{cfu}$ using 100, which corresponds to a concentration of $100 \mathrm{cfu} / \mathrm{mL}$ of milk. The Chelex boiling extraction method, combined with PCR-based fluorescent detection, thus, achieved interesting sensitivity that ranged from 100 to $500 \mathrm{cfu}$ in $1 \mathrm{~mL}$ of milk. Detection is limited, however, to the volume used for the PCR assay. In the present assay, the volume was limited to $2 \mu \mathrm{L}$ from the $200-\mu \mathrm{L}$ extract, equivalent to $1: 100$ of $1 \mathrm{~mL}$ of milk as the starting material. For a given analytical specificity of $500 \mathrm{cfu} / \mathrm{mL}$, it corresponds to 5 genome equivalents in the PCR assay. Indeed, a $2-\mu \mathrm{L}$ extract used in PCR would correspond to 5 genome equivalents, given that $500 \mathrm{cfu}$ is resuspended into the $200-\mu \mathrm{L}$ extract $(2.5 \mathrm{cfu} / \mu \mathrm{L})$. Whereas one substantial benefit of a PCR assay over conventional microbiological detection can be achieved with frozen samples with bacterial viability lost (Schukken et al., 1989), this molecular technique depends on the number of genomic DNA-cfu equivalents put into the PCR assay, as well as the effect of contaminants that could inhibit subsequent PCR reactions. The Chelex boiling extraction method is relatively clean and effective for detecting as few as 5 genome equivalents per PCR reaction.

The bacterial DNA extraction procedure was a main focus in the present study because many reports proposing a molecular method underestimated this former step for molecular detection (Brehm-Stecher et al., 2009). The extraction was designed to meet the study's main criteria (low cost, high throughput capacity, and good sensitivity). During the optimization step, several constraints linked to the physical and biochemical aspects of milk were encountered. The first significant aspect was the addition of Tergitol, a detergent that liquefies the fat layer. The addition of 
a detergent increased the fluidity of the fat layer to some extent, preventing it from sticking to the walls of the tube during decantation. Other works proposed the use of detergent solutions, with Triton X-100 being the most frequently used (Hotzel et al., 1996; Champagne et al., 1997; Muramatsu et al., 1997; O'Mahony and Hill, 2004; Cremonesi et al., 2006). However, Tergitol detergent was chosen because of its inability to lyse gram-negative cell walls, as shown elsewhere (Mayrl et al., 2009). Eliminating the fat layer, proteins, and calcium ions was the next step toward obtaining DNA suitable for the downstream PCR reaction. PCR inhibition is certainly an issue of great concern when working with samples purified from milk. To trap divalent ions, the addition of EDTA, and the Chelex resin were definitely effective for the isolation of coarse, relatively clean, amplifiable DNA from mastitic samples. Rapid DNA extraction using a Chelex-based agent has also been found to be successful for detecting pathogens in milk (Minarovičová et al., 2010). It appears that EDTA destabilizes casein micelles by calcium ion deprivation (Grattepanche et al., 2005), which might decrease micelle precipitation during centrifugation. The EDTA treatment was generally sufficient and left a thin pellet. For mastitic samples presenting abundant clots and flakes, however, these physical alterations of milk are challenging for DNA extraction procedures, especially ones designed for high-throughput applications. The principle based on unspecific capture of bacteria to ligand-coated magnetic particles and subsequent binding of the bacterial DNA to the same bead surface (Rudi et al., 1998; Tan and Yiap, 2009) has proven useful for the molecular diagnosis of bacterially derived diseases (Anglès d'Auriac et al., 2007), including mastitis (present study). The GenFind V2 DNA purification protocol greatly improved PCR detection, as was the case, for example, with some milk samples that had been stored for years (data not shown). The GenFind protocol worked with a 96-well plate and was, thus, well adapted for high-throughput clinical sample analysis.

In conclusion, the authors are confident that the proposed approach is specifically adapted for highthroughput analysis and shows excellent analytical specificity and sensitivity. Although some constraints were imposed on the extraction and detection protocol (no organic solvents or hazardous chemicals), the motivation behind its development was also to keep the cost of the methodology as low as possible (less than US\$5) to open it up to large-scale analysis for mastitis diagnosis. The proposed Chelex PCR-based approach presents numerous technical benefits that make it appropriate for the implementation of PCR assays in routine mastitis-testing programs.

\section{ACKNOWLEDGMENTS}

This work was supported by grants from the Dairy Cattle Genetics Research and Development (DairyGen) Council (Ottawa, ON, Canada) and from Agriculture and Agri-Food Canada (AAFC; Ottawa, ON), as well as by master's and doctoral scholarships awarded under the Canadian Dairy Commission scholarship program in collaboration with Novalait Inc. (Sainte Foy, QC, Canada). The authors thank the following individuals: Jessika St-Pierre and Catherine Thibault (AAFC) for providing technical assistance in gene target selection and microbiological analysis during the preliminary experiments; Serge Messier (clinical bacteriology laboratory, Faculté de Médecine Vétérinaire, Université de Montréal, QC, Canada) and Doris Poole (Atlantic Veterinary College, University of Prince Edward Island, Charlottetown, PE, Canada) for providing the mastitic samples and Ruth N. Zadoks (Department of Food Science and Quality Milk Production Services, Cornell University, Ithaca, NY) for providing expertise in epidemiology and bacteriology.

\section{REFERENCES}

Altschul, S. F., W. Gish, W. Miller, E. W. Myers, and D. J. Lipman. 1990. Basic local alignment search tool. J. Mol. Biol. 215:403410.

Anglès d'Auriac, M., U. H. Refseth, M. Espelund, H. Moi, G. Størvold, and S. Jeansson. 2007. A new automated method for isolation of Chlamydia trachomatis from urine eliminates inhibition and increases robustness for NAAT systems. J. Microbiol. Methods 70:416-423.

Bar, D., L. W. Tauer, G. Bennett, R. N. González, J. A. Hertl, Y. H. Schukken, H. F. Schulte, F. L. Welcome, and Y. T. Gröhn. 2008. The cost of generic clinical mastitis in dairy cows as estimated by using dynamic programming. J. Dairy Sci. 91:2205-2214.

Benson, D. A., I. Karsch-Mizrachi, D. J. Lipman, J. Ostell, and E. W. Sayers. 2010. GenBank. Nucleic Acids Res. 38(Database issue):D46-D51.

Biddle, M. K., L. K. Fox, and D. D. Hancock. 2003. Patterns of mycoplasma shedding in the milk of dairy cows with intramammary mycoplasma infection. J. Am. Vet. Med. Assoc. 223:1163-1166.

Brehm-Stecher, B., C. Young, L. A. Jaykus, and M. L. Tortorello. 2009. Sample preparation: The forgotten beginning. J. Food Prot. 72:1774-1789.

Champagne, C. P., N. J. Gardner, J. Fontaine, and J. Richard. 1997. Determination of viable bacterial populations in raw milk within 20 minutes by using a direct epifluorescent filter technique. J. Food Prot. 60:874-876

Cole, J. R., Q. Wang, E. Cardenas, J. Fish, B. Chai, R. J. Farris, A. S. Kulam-Syed-Mohideen, D. M. McGarrell, T. Marsh, G. M. Garrity, and J. M. Tiedje. 2009. The Ribosomal Database Project: improved alignments and new tools for rRNA analysis. Nucleic Acids Res. 37(Database issue):D141-D145.

Cremonesi, P., B. Castiglioni, G. Malferrari, I. Biunno, C. Vimercati, P. Moroni, S. Morandi, and M. Luzzana. 2006. Technical note: Improved method for rapid DNA extraction of mastitis pathogens directly from milk. J. Dairy Sci. 89:163-169.

Cremonesi, P., G. Pisoni, M. Severgnini, C. Consolandi, P. Moroni, M. Raschetti, and B. Castiglioni. 2009. Pathogen detection in milk samples by ligation detection reaction-mediated universal array method. J. Dairy Sci. 92:3027-3039. 
Day, S. P., A. Hudson, A. Mast, T. Sander, M. Curtis, S. Olson, L. Chehak, N. Quigley, J. Ledford, B. Yen-Lieberman, D. Kohn, D. I. Quigley, and M. Olson. 2009. Analytical performance of the Investigational Use Only Cervista HPV HR test as determined by a multi-center study. J. Clin. Virol. 45(Suppl. 1):S63-S72.

Dingwell, R. T., K. E. Leslie, Y. H. Schukken, J. M. Sargeant, and L. L. Timms. 2003. Evaluation of the California mastitis test to detect an intramammary infection with a major pathogen in early lactation dairy cows. Can. Vet. J. 44:413-415.

Giese, S. B., and P. Ahrens. 2000. Detection of Mycobacterium avium ssp. paratuberculosis in milk from clinically affected cows by PCR and culture. Vet. Microbiol. 77:291-297.

Gillespie, B. E., and S. P. Oliver. 2005. Simultaneous detection of mastitis pathogens, Staphylococcus aureus, Streptococcus uberis, and Streptococcus agalactiae by multiplex real-time polymerase chain reaction. J. Dairy Sci. 88:3510-3518.

Giraffa, G., L. Rossetti, and E. Neviani. 2000. An evaluation of Chelex-based DNA purification protocols for the typing of lactic acid bacteria. J. Microbiol. Methods 42:175-184.

Graber, H. U., M. G. Casey, J. Naskova, A. Steiner, and W. Schaeren. 2007. Development of a highly sensitive and specific assay to detect Staphylococcus aureus in bovine mastitic milk. J. Dairy Sci. 90:4661-4669

Grattepanche, F., C. Lacroix, P. Audet, and G. Lapointe. 2005. Quantification by real-time PCR of Lactococcus lactis ssp. cremoris in milk fermented by a mixed culture. Appl. Microbiol. Biotechnol. 66:414-421.

Hotzel, H., K. Sachse, and H. Pfützner. 1996. Rapid detection of Mycoplasma bovis in milk samples and nasal swabs using the polymerase chain reaction. J. Appl. Bacteriol. 80:505-510.

International Dairy Federation. 1999. Suggested interpretation of mastitis terminology. Bull. No. 338:3-26. International Dairy Federation, Brussels, Belgium.

Kim, C. H., M. Khan, D. E. Morin, W. L. Hurley, D. N. Tripathy, M. Kehrli Jr., A. O. Oluoch, and I. Kakoma. 2001. Optimization of the PCR for detection of Staphylococcus aureus nuc gene in bovine milk. J. Dairy Sci. 84:74-83.

Koskinen, M. T., J. Holopainen, S. Pyörälä, P. Bredbacka, A. Pitkälä, H. W. Barkema, R. Bexiga, J. Roberson, L. Sølverød, R. Piccinini, D. Kelton, H. Lehmusto, S. Niskala, and L. Salmikivi. 2009. Analytical specificity and sensitivity of a real-time polymerase chain reaction assay for identification of bovine mastitis pathogens. J. Dairy Sci. 92:952-959.

Kuang, Y., K. Tani, A. J. Synnott, K. Ohshima, H. Higuchi, H. Nagahata, and Y. Tanji. 2009. Characterization of bacterial population of raw milk from bovine mastitis by culture-independent PCRDGGE method. Biochem. Eng. J. 45:76-81.

Longo, M. C., M. S. Berninger, and J. L. Hartley. 1990. Use of uracil DNA glycosylase to control carry-over contamination in polymerase chain reactions. Gene 93:125-128.

Luther, D. A., R. A. Almeida, and S. P. Oliver. 2008. Elucidation of the DNA sequence of Streptococcus uberis adhesion molecule gene (sua) and detection of sua in strains of Streptococcus uberis isolated from geographically diverse locations. Vet. Microbiol. 128:304-312

Martin, S. W. 1984. Estimating disease prevalence and the interpretation of screening. Prev. Vet. Med. 2:463-472.

Mayrl, E., B. Roeder, P. Mester, M. Wagner, and P. Rossmanith. 2009. Broad range evaluation of the matrix solubilization (matrix lysis) strategy for direct enumeration of foodborne pathogens by nucleic acids technologies. J. Food Prot. 72:1225-1233.

Minarovičová, J., J. Lopašovská, L. Valík, and T. Kuchta. 2010. A method for the detection of Cryptosporidium parvum oocysts in milk based on microfiltration and real-time polymerase chain reaction. Food Anal. Methods 4:116-120.

Muramatsu, Y., T. Yanase, T. Okabayashi, H. Ueno, and C. Morita 1997. Detection of Coxiella burnetii in cow's milk by PCR-enzymelinked immunosorbent assay combined with a novel sample preparation method. Appl. Environ. Microbiol. 63:2142-2146.
NMC. 2004. Microbiological Procedures for Use in the Diagnosis of Bovine Udder Infection and Determination of Milk Quality. 4th ed. National Mastitis Council, Verona, WI.

O'Mahony, J., and C. Hill. 2004. Rapid real-time PCR assay for detection and quantitation of Mycobacterium avium ssp. paratuberculosis DNA in artificially contaminated milk. Appl. Environ. Microbiol. 70:4561-4568.

Olde Riekerink, R. G. M., H. W. Barkema, D. F. Kelton, and D. T. Scholl. 2008. Incidence rate of clinical mastitis on Canadian dairy farms. J. Dairy Sci. 91:1366-1377.

Pruvost, M., T. Grange, and E.-M. Geigl. 2005. Minimizing DNA contamination by using UNG-coupled quantitative real-time PCR on degraded DNA samples: Application to ancient DNA studies. Biotechniques 38:569-575.

Quaglia, N. C., G. Normanno, A. Dambrosio, G. V. Celano, A. Parisi, A. Firinu, and C. Buonavoglia. 2005. Multiplex-touchdown PCR assay for the detection and genotyping of Helicobacter pylori from artificially contaminated sheep milk. J. Food Prot. 68:21362139

Riyaz-Ul-Hassan, S., S. Syed, S. Johri, V. Verma, and G. N. Qazi 2009. Application of a multiplex PCR assay for the detection of Shigella, Escherichia coli and Shiga toxin-producing Esch. coli in milk. J. Dairy Res. 76:188-194.

Roy, J.-P., D. Du Tremblay, L. DesCôteaux, S. Messier, D. Scholl, and É. Bouchard. 2007. Effect of precalving intramammary treatment with pirlimycin in nulliparous Holstein heifers. Can. J. Vet. Res. 71:283-291.

Rudi, K., F. Larsen, and K. S. Jakobsen. 1998. Detection of toxinproducing cyanobacteria by use of paramagnetic beads for cell concentration and DNA purification. Appl. Environ. Microbiol. 64:34-37.

Santos, O. C., E. M. Barros, M. A. Brito, C. Bastos Mdo, K. R. Dos Santos, and M. Giambiagi-Demarval. 2008. Identification of coagulase-negative staphylococci from bovine mastitis using RFLP-PCR of the groEL gene. Vet. Microbiol. 130:134-140.

Schukken, Y. H., J. A. H. Smit, F. J. Grommers, D. Vandegeer, and A. Brand. 1989. Effect of freezing on bacteriologic culturing of mastitis milk samples. J. Dairy Sci. 72:1900-1906.

Siddiqui, H., A. J. Nederbragt, and K. S. Jakobsen. 2009. A solidphase method for preparing human DNA from urine for diagnostic purposes. Clin. Biochem. 42:1128-1135.

Supré, K., S. De Vliegher, O. C. Sampimon, R. N. Zadoks, M. Vaneechoutte, M. Baele, E. De Graef, S. Piepers, and F. Haesebrouck. 2009. Technical note: Use of transfer RNA-intergenic spacer PCR combined with capillary electrophoresis to identify coagulase-negative Staphylococcus species originating from bovine milk and teat apices. J. Dairy Sci. 92:3204-3210.

Tan, S. C., and B. C. Yiap. 2009. DNA, RNA, and protein extraction: The past and the present. J. Biomed. Biotechnol. 2009:574398.

Taponen, S., L. Salmikivi, H. Simojoki, M. T. Koskinen, and S. Pyörälä 2009. Real-time polymerase chain reaction-based identification of bacteria in milk samples from bovine clinical mastitis with no growth in conventional culturing. J. Dairy Sci. 92:2610-2617.

Therese, K. L., A. R. Anand, and H. N. Madhavan. 1998. Polymerase chain reaction in the diagnosis of bacterial endophthalmitis. Br. J. Ophthalmol. 82:1078-1082.

Weisburg, W. G., S. M. Barns, D. A. Pelletier, and D. J. Lane. 1991 16S ribosomal DNA amplification for phylogenetic study. J. Bacteriol. 173:697-703.

Wilson, K. 2001. Preparation of genomic DNA from bacteria. Pages 1-5 in Current Protocols Molecular Biology. Chapter 2: Unit 2 4. F. M. Ausubel, R. Brent, R. E. Kingston, D. D. Moore, J. G. Seidman, J. A. Smith, and K. Struhl, ed. John Wiley and Sons Inc., Mississauga, ON, Canada.

Zadoks, R. N., and J. L. Watts. 2009. Species identification of coagulase-negative staphylococci: Genotyping is superior to phenotyping. Vet. Microbiol. 134:20-28. 